\title{
Communications
}

\section{Efficient Oxidation of Benzylic Alcohols to Aldehydes and Ketones in Ionic Liquid Using $\mathrm{N}$-Chlorosuccinimide/ $/ \mathrm{AlCl}_{3} \cdot 6 \mathrm{H}_{2} \mathrm{O}$}

\author{
Soon Uk Chang, Jai Ha Cho, and Jong Chan Lee* \\ Department of Chemisin, Chung-Ang University. Seout 156-756. Korea. "E-mail: joleelàcau.ac:kr \\ Recened August 20,2007
}

Key Words : Benzylic alcohols, Carbonyl, Ionic liquid, Oxidation

Evolution of environmentally friendly synthesis is a paramount goal of the present day organic chemistry. Most promising approaches to the green synthetic methods commonly involve the replacement of ordinary procedures by less harmful catalytic processes utilizing transition metals. the utilization of nontoxic reaction media, and use of recyclable reaction media. ${ }^{1.2}$ In recent years, ionic liquids have been acknowledged as green alternatives to the toxic and volatile organic solvents for various chemical reactions." A variety of reactions such as hydrogenation, ${ }^{+}$hydroformylation, ${ }^{5}$ carbon-carbon bond forming reactions, "Diels-Alder reactions, ${ }^{7}$ Heck reactions, ${ }^{8}$ Friedel-Crafts reactions, ${ }^{9}$ and oligomerization reactions ${ }^{10}$ have been reported in the literature using ionic liquid as reaction media.

Oxidation of alcohols to the corresponding carbonyl compounds is the most valuable transformations in organic chemistry as carbonyl groups are widely present in structures of various pharmaceuticals, industrially important chemicals, and natural products." Among other protocols for obtaining carbonyl compounds, the oxidation of benzylic alcohols to the corresponding aldehydes or ketones is a fundamental method in academia and industrial synthesis. ${ }^{12}$ Oxidation of benzylic alcohols commonly achieved by a number of methods including use of reagents such as nitric acid, $^{\text {I' }}$ DMSO/HBr, ${ }^{14}$ [hydroxy(tosyloxy)iodo]benzene. ${ }^{15}$ and iodobenzene diacetate on alumina. ${ }^{16}$ However, above mentioned methods usually conducted under harsh reaction conditions and utilized toxic organic solvents. In addition, in other known procedures, use of unstable and environmentally hazardous oxidizing agents like $\mathrm{MnO}_{2}, \mathrm{CrO}_{3}$ and $\mathrm{SeO}_{2}$ are necessary for the oxidation of benzylic alcohols. ${ }^{17}$ Use of $N$-chlorosuccinimide in oxidation reactions are highly promising due to its ready availability, ease of manipulation, and less toxic nature. However, reported NCS induced oxidation methods invariably utilized bases such as $\mathrm{K}_{2} \mathrm{CO}_{3}{ }^{18}$ $\mathrm{EtN}(i-\mathrm{Pr})_{2,}{ }^{19}$ and $\mathrm{NaHCO}_{3 .}{ }^{20}$ Therefore, it is highly desirable to develop the NCS promoted oxidation procedure of benzylic alcohols avoiding use of basic reaction conditions.

As a part of our ongoing project on the use of aluminum chloride hexahydrate in ionic liquid, we attempted to develop new NCS induced oxidation of benzylic alcohols to aldehydes and ketones. To the best of our knowledge. use of<smiles>[R]C(=O)c1ccc([R])cc1[R]</smiles>

aluminum chloride hexahydrate for the activation of NCS is unprecedented. Our new protocol involves the reaction of benzylic alcohols with NCS in the presence of aluminum chloride hexahydrate in I-butyl-3-methylimidazolium tetrafluoroborate $\left([\right.$ bmim $\left.] \mathrm{BF}_{1}\right)$, ionic liquid medium. Treatment of benzylic alcohols with aluminum chloride hexahydrate ( 0.5 equiv) and NCS ( 1.0 equiv) in [bmim]BF $(1 \mathrm{~mL})$ at 60 ${ }^{\prime} \mathrm{C}$ ' for $\mathrm{I}-2 \mathrm{~h}$ cleanly afforded the corresponding carbonyl compounds (Scheme 1). At the present reaction conditions, benzylic alcohols were efficiently converted into the corresponding aldehydes and ketones in excellent yields. The results are summarized in Table I. As shown in the Table 1,

Table 1. Oxidation of benzylic alcohols to aldehydes and ketones in $[\mathrm{bmim}] \mathrm{BF}_{4}$ ionic licquid

\begin{tabular}{|c|c|c|c|c|}
\hline Entry & Substrate & Product & $\begin{array}{c}\text { Time } \\
\text { (h) }\end{array}$ & $\begin{array}{l}\text { Yiuld } \\
(\%)^{r}\end{array}$ \\
\hline 1 & $\mathrm{C}_{6} \mathrm{H}_{5} \mathrm{C}_{2} \mathrm{H}_{2} \mathrm{OH}$ & $\mathrm{C}_{4} \mathrm{H}_{5} \mathrm{C} \mathrm{HO}$ & 1 & 95 \\
\hline 2 & $4-\mathrm{CH}_{3} \mathrm{C}_{6} \mathrm{H}_{4} \mathrm{C}_{2} \mathrm{OH}$ & 4- $\mathrm{CH}_{3} \mathrm{C}_{4} \mathrm{H}_{4} \mathrm{CH}_{2} \mathrm{CHO}$ & 1 & 95 \\
\hline 3 & $4-\mathrm{FC}_{6} \mathrm{H}_{4} \mathrm{CH}_{2} \mathrm{OH}$ & $4-\mathrm{FC}_{6}, \mathrm{H}_{4} \mathrm{CHO}$ & 1.5 & 95 \\
\hline 4 & $4-\mathrm{ClC}_{6} \mathrm{H}_{4} \mathrm{CH}_{2} \mathrm{OH}$ & $4-\mathrm{ClC}_{2} \mathrm{H}_{4} \mathrm{CHO}$ & 1.5 & 95 \\
\hline 5 & $4-\mathrm{BrC}_{3} \mathrm{H}_{4} \mathrm{CH}_{2} \mathrm{OH}$ & $4-\mathrm{BrC}_{4} \mathrm{H}_{4} \mathrm{CHO}$ & 1.5 & 95 \\
\hline 6 & $4-\mathrm{NO}_{2} \mathrm{C}_{6} \mathrm{H}_{4} \mathrm{CH}_{2} \mathrm{OH}$ & $4-\mathrm{NO}_{2} \mathrm{C}_{4} \mathrm{H}_{4} \mathrm{CHO}$ & 2 & 75 \\
\hline 7 & $\mathrm{C}_{1 !} \mathrm{H}_{7} \mathrm{C}_{2} \mathrm{H}_{2} \mathrm{OH}$ & $\mathrm{C}_{\mathrm{li}} \mathrm{H}_{7} \mathrm{C} \mathrm{HO}$ & 2 & 80 \\
\hline 8 & 2.5- $\left(\mathrm{CH}_{3} \mathrm{O}_{2} \mathrm{C}_{6} \mathrm{H}_{3} \mathrm{CH}_{2} \mathrm{OH}\right.$ & $2.5-\left(\mathrm{CH}_{3} \mathrm{O}\right)_{2} \mathrm{C}_{4} \mathrm{H}_{3} \mathrm{COH}$ & 2 & 80 \\
\hline 9 & $\mathrm{C}_{6}, \mathrm{H}_{5} \mathrm{CH}(\mathrm{OH}) \mathrm{CH}_{3}$ & $\mathrm{C}_{4} \mathrm{H}_{5} \mathrm{COCH}_{3}$ & 1 & 95 \\
\hline 10 & $\mathrm{C}_{6}, \mathrm{H}_{5} \mathrm{CH}(\mathrm{OH}) \mathrm{CH}_{2} \mathrm{CH}_{3}$ & $\mathrm{C}_{4} \mathrm{H}_{5} \mathrm{COCH}_{2} \mathrm{CH}_{3}$ & 1.5 & 90 \\
\hline 11 & $4-\mathrm{CH}_{3} \mathrm{C}_{6} \mathrm{H}_{4} \mathrm{C} \mathrm{H}(\mathrm{OH}) \mathrm{CH}_{3}$ & $4-\mathrm{CH}_{3} \mathrm{C}_{4} \mathrm{H}_{4} \mathrm{COCH}_{3}$ & 2 & 95 \\
\hline 12 & $4-\mathrm{ClC}_{6} \mathrm{H}_{4} \mathrm{CH}(\mathrm{OH}) \mathrm{CH}_{3}$ & $4-\mathrm{ClC}_{3} \mathrm{H}_{4} \mathrm{COCH}_{3}$ & 2 & 95 \\
\hline 13 & $4-\mathrm{CH}_{3} \mathrm{OC}_{2}{ }_{2} \mathrm{H}_{4} \mathrm{CH}(\mathrm{OH}) \mathrm{CH}_{3}$ & $4-\mathrm{CH}_{3} \mathrm{OC}_{6} \mathrm{H}_{4} \mathrm{COCH}_{3}$ & 2 & 95 \\
\hline 14 & $\mathrm{C}_{i}, \mathrm{H}_{s} \mathrm{CH}(\mathrm{OH}) \mathrm{C}_{\phi} \mathrm{H}_{s}$ & $\mathrm{C}_{6} \mathrm{H}_{5} \mathrm{C}^{-} \mathrm{OC}_{6} \mathrm{H}_{5}$ & 2 & 90 \\
\hline 15 & $\mathrm{C}_{i}, \mathrm{H}_{5} \mathrm{CH}(\mathrm{OH}) \mathrm{COC}_{6} \mathrm{H}_{5}$ & $\mathrm{C}_{k_{1}} \mathrm{H}_{4} \mathrm{C}^{-} \mathrm{OCOC}_{4} \mathrm{H}_{4}$ & 2 & 90 \\
\hline 16 & $\mathrm{C}_{1} \mathrm{H}_{7} \mathrm{CH}(\mathrm{OH}) \mathrm{CH}_{3}$ & $\mathrm{C}_{1 \mathrm{l} 1} \mathrm{H}_{7} \mathrm{C}^{-} \mathrm{OCH}$ & 2 & 85 \\
\hline
\end{tabular}

\footnotetext{
"Isolated yiclds.
} 
the electron donating and electron withdrawing substituents on the aromatic rings generally did not affect the yields of oxidation reactions. At the present reaction conditions. the oxidation of primary benzylic alcohols (entries 1-6) generally took shorter reaction times than the cases of secondary benzylic alcohols. Further extension of this method for the oxidation of aliphatic alcohols (entries 7 and 16) also gave the carbonyl compounds in high yields. Changing of anion of ionic liquid from $\mathrm{BF}_{4}$ to $\mathrm{PF}_{6}$ generally gave inferior yields of the oxidation products. Presumably, the oxidation reactions occurred by the interaction of alcohols with the chloroium ion preformed by interaction of NCS with aluminum chloride hexalhydrate. The first utilization of readily available and stable aluminum chloride hexahydrate for the activation of NCS should makes this method a valuable addition to the other alternative methods for the oxidation of benzylic alcohols. Recycling of ionic liquid with three runs of reactions gave comparable yields. General procedures of oxidation reaction is as follows: To a stirred solution of benzylic alcohol (1.0 nmol) in [bmim] $\mathrm{BF}_{4}$ (l $\mathrm{mL}$ ) was added $N$-chlorosuccinimide $(0.133 \mathrm{~g}, 1.0 \mathrm{mumol})$ and aluminum chloride hexahydrate $(0.121 \mathrm{~g}, 0.5 \mathrm{mmol})$ and stirring was continued at $60^{\circ} \mathrm{C}$ for the time indicated in the Table 1. After completion of the reaction, the product was extracted with dichloromethane $(25 \mathrm{~mL})$, washed with water $(40 \mathrm{~mL})$, and dried over $\mathrm{MgSO}_{4}$. The solvent was removed in vacio and the crude mixture was purified by silica-gel chromatography using ethyl acetate-hexane (1:3) to give the pure carbonyl conpound.

In conclusion. we have developed a new and efficient method for the preparation of aldehydes and ketones from the reaction of benzylic alcohols with NCS and aluminum chloride hexalyydrate in environmentally friendly [bminl] $\mathrm{BF}_{4}$ ionic liquid

Acknowledgement. This research was supported by the Chung-Ang University Research Scholarship Grants in 2007.

\section{References}

1. Beller, M: Bolm, C. Transition Metals for Organic Symhesis:
Wiely-VCH: Weithheinn. 1998.

2. Kochi. M. Green Reaction Media for Organic Sinthesis: Blackwell Publishing Ltd: Osford. 2005.

3. (a) Welton. T. In Ionic Liquids in Synthesis, Wasserscheid. P. Ed: VCH-Wiley: Weinheim, 2002. (b) Jorapur. Y. R.: Chi. D. Y. Bull. Korean Chem. Soc. 2006. 27, 345

4. (a) Lee. S.-G.: Jung. H. R.: Kim. K. M.: Song. C. E.: Cho. C. G. Bull. Korean Chen. Soc. 2003. 24. 1407. (b) Brown. R. A.: Pollet. P.: Mckoon. E.: Eckert. C. A.: Liotta. C. L.: Jessop. P. G. J. Ain. Chem. Soc. 2001, 123. 1254.

5. (a) Chauvin. Y.: Mussmann, L.: Olivier. H. Angew. Chem. Int Ed. 1995. 34. 2698. (b) Favre, F: Olivier, H.: Commereuc. D: Saussine. L. Chen Conmt 2001. 1360.

6. (a) Chauvit1. Y.: Olivier. H. Chemtech 1995. 26. (b) Simon. L C.: Dupont. T.: De Souza. R. F. Appl Catal A 1998. 175. 215. (c) Jorapur, Y. R.: Chi, D. Y. Bull Korean Chem. Soc, 2006. 27. 345 .

7. Fischer. T: Sethi, A: Welton, T.; Woolf. J. Tetrahedron Lett. 1999. +0.793

8. Chauvin. Y.: Mussmann. L:: Olivier. H. Angew: Chent Int. Ed. 1995. 3H. 2698 .

9. Boon. J. A.; Levisky, J. A.; Pflug. J. L; Wilkes. J. S. J. Org Chem. 1986, 51,480

10. (a) Da Rosa. R. G.: De Souza. M. O.: De Souza. R. F. J. Mfol. Catal. A 1997. 120. 55. (b) Dullius. T. E. L.: Suarez. P. A. Z. Einloft. S.: De Souza. R. F.: Dupont. T.: Fischer. T.: Decian. A. Organonetallics 1998. 17.815.

11. (a) Pybus, D. H; Sell. C. S. The Chemisty of Fragrances, RCS Paperbacks: Cambrige, 1999. (b) Singh. R. P.; Subbarao, H. N:; Dev, S. Tetrahedron 1979. 35, 1789.

12. In Conprehensive Organic Swhthesis: Ley. S. V.: Madin. A.: Trost. B. M.: Flemming. I.. Eds.: Pergamon Press: Osford. 1991: vol. 7. pp 305-327.

13. Strazzolini. P.: Runcio. A. Eur. J. Ong. Chem. 2003. 526

14. Li. C.: Xu, Y: Lu, M.: Zhao. Z.: Liu, L.; Zhao. Z.: Cui. Y.: Zheng. P.; Ji, X.: Gao. G Swlett 2002. 2041.

15. Lee. J. C.: Lee. Y. Y.: Lee. S. J. Tetrahedron Lett. 2004. 45. 4939.

16. Varma. R. S.: Dahiya. R.: Saini. R. K. Tetrohedron Lett. 1997. 38. 7029.

17. March. J. Adwanced Organic Chemisny: Reactions, Mechanisms and Stuctwe, the ed.: John Wiley \& Sons: New York. 1992.

18. Matsuo. T.-I.: Iida. D.: Yamanaka. H.: Mukaiyama. T. Tetrohedron 2003. 59.6739

19. Matsuo. T.-I.: Kawana. A.: Yamanaka. H.: Kamiyama. H. Bull. Chem. Soc. Jpn. 2003. 76. 1433.

20. Einhorn, J.: Einhom. C.; Ratajezak. F.: Pierre. J.-L. J. Org. Chem. 1996. 61,7452 